\title{
On the Cover of this Issue: Cyclic Strain Heterogeneity and Damage Formation in Rolled Magnesium by N. Shafaghi, E. Kapan, and C.C. Aydıner
}

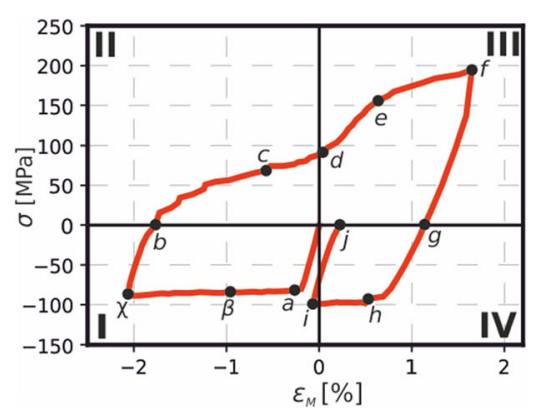

Cyclic Strain Heterogeneity and Damage Formation in Rolled Magnesium

by N. Shafaghi, E. Kapan, and C.C. Aydıner

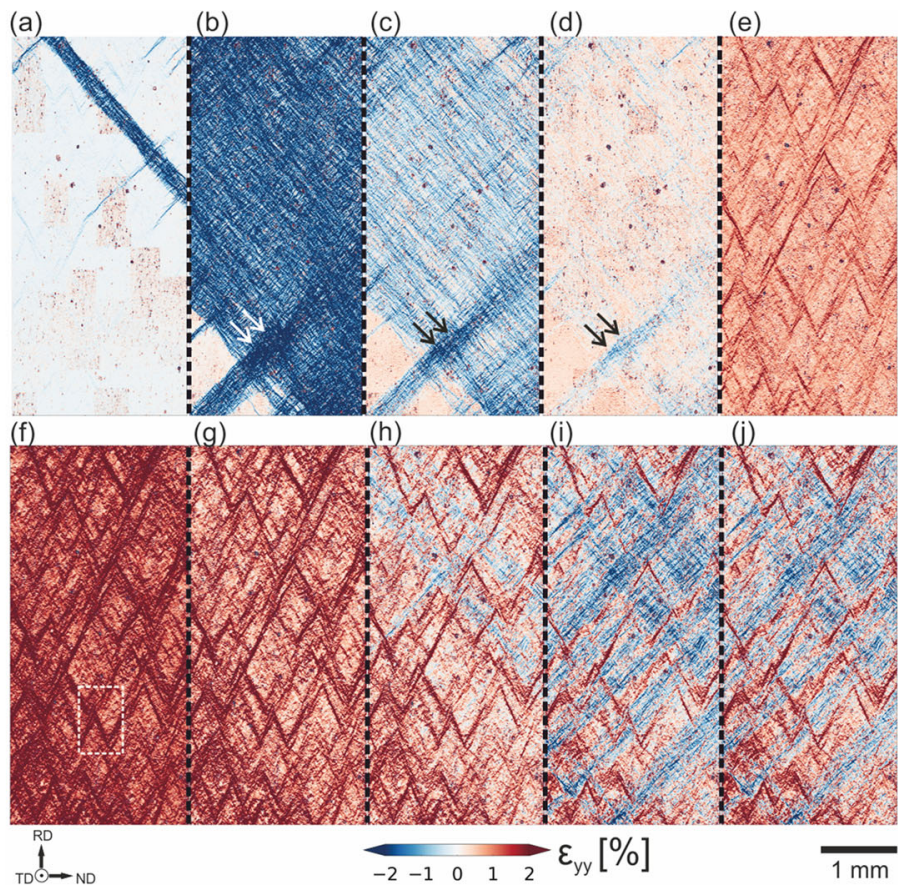

